\title{
骨組織における機能的グルタミン酸シグナリング
}

\author{
檜井栄一
}

\section{Functional Glutamate Signaling in Bone}

\author{
Eiichi HINOI \\ Laboratory of Molecular Pharmacology, Division of Pharmaceutical Sciences, \\ Kanazawa University Graduate School of Natural Science and Technology, \\ Kakuma-machi, Kanazawa, Ishikawa 920-1192, Japan
}

(Received May 29, 2010)

\begin{abstract}
L-glutamate (Glu) has been thought to be an excitatory amino acid neurotransmitter in the mammalian central nervous system. Relatively little attention has been paid to the functional expression of Glu signaling machineries in peripheral tissues. In this review, therefore, we summarized the possible signaling by Glu as an extracellular signal mediator in mechanisms underlying maintenance of cellular homeostasis in bone tissues. Constitutive expression of mRNAs for particular Glu receptors (GluR), Glu transporters (GluT) was found in osteoblasts. $N$-methyl-D-aspartic acid receptor antagonist MK-801 significantly prevented differentiation and maturation of osteoblasts through modulation of expression of Runx2. DL- $\alpha$-amino-3-hydroxy-5-methylisoxazole-4-propionic acid significantly increased the release of endogenous Glu from osteoblasts through its receptor expressed by osteoblasts. In addition, $\left[{ }^{3} \mathrm{H}\right] \mathrm{Glu}$ uptake was also seen in a temperature- and sodium-dependent manner with pharmacological profiles similar to those for brain GluTs in osteoblasts. Although no mRNA expression was found for all GluRs examined in primary cultured mouse osteoclasts, constitutive expression of mRNAs was seen with GluT, such as excitatory amino acid transporters and cystine/Glu antiporter. Glu markedly inhibited osteoclastogenesis in a manner sensitive to the antiporter inhibitor. The systemic administration of Glu significantly prevented the decreased bone mineral density in addition to increased osteoclastic indices in ovariectomized mice in vivo. Taken together, Glu could play a pivotal role in mechanisms underlying the maintenance of cellular homeostasis as an extracellular signal mediator in bone.
\end{abstract}

Key words_— bone; glutamate; osteoblast; osteoclast; osteoporosis

\section{1.はじめに}

骨組織では骨芽細胞による骨形成と破骨細胞によ る骨吸収が絶えず繰り返される，いわゆる骨リモデ リングが営まれており, 骨の形態や機能が維持され ている.このバランスが一旦破綻すると，骨大理石 症や骨粗鬆症などのいわゆる骨代謝性疾患が引き起 こされる，現在日本における骨粗鬆症患者は，1100 万人を超えると推定されており，そのうちの 800 万 人が閉経後骨粗鬆症患者であるが，実際に治療を受 けている患者は 200 万人に過ぎないと推定されてい る. 現在, 日本女性の平均寿命は 85 歳を超えてお り，閉経後からの人生は約 35 年にも及ぶため，閉

金沢大学医薬保健研究域薬学系薬物学研究室 (T9201192 石川県金沢市角間町)

e-mail: hinoi@p.kanazawa-u.ac.jp

本総説は, 平成 21 年度日本薬学会北陸支部学術奨励賞 の受賞を記念して記述したものである.
経後の Quality of life (QOL) や Activities of daily living の維持向上は非常に重要である。しかしなが ら骨粗鬆症に起因する骨折は寝たきりにつながる可 能性もあり，同疾患は患者の QOL を大きく低下さ せ，超高齢化社会を迎えたわが国において医療費高 騰の大きな原因の 1 つにもなつている．このような 事実を勘案すると同疾患に対する効果的な治療法の 確立及び治療薬の開発は差し迫つた社会的緊急課題 である。

Glutamic acid（Glu）は中枢神経系において神経 伝達物質として機能する。すなわち Glu は神経細 胞の興奮に伴い前シナプスからシナプス間隙中へ放 出され，後シナプスに存在する Glu レセプター （GluR）に作用する. シナプス間隙中に放出された Gluの一部は, Gluトランスポーター（GluT）を 介してシナプス周辺のグリア細胞 (アストロサイト) へ取り込まれる。 


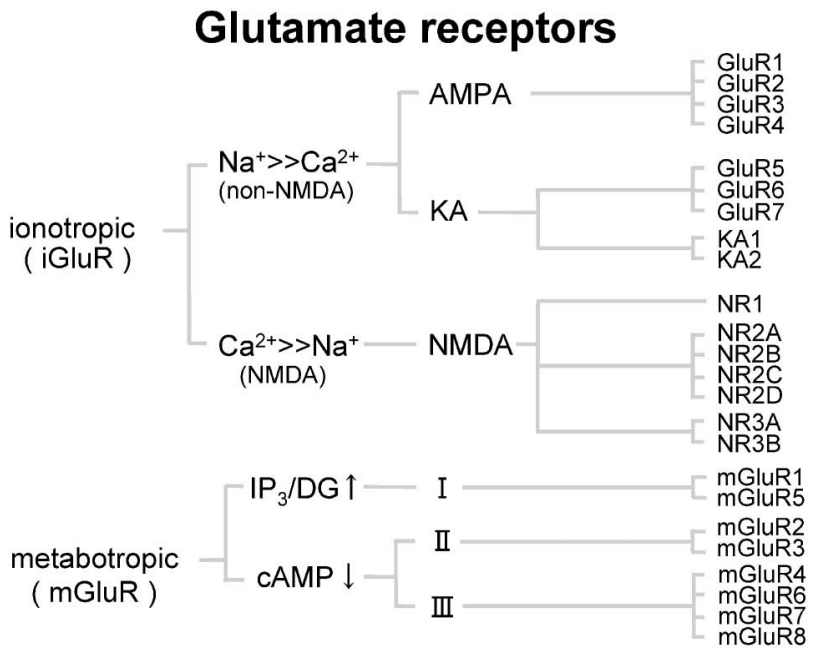

Fig. 1. Classification of GluRs

Glu シグナルを受け取る GluR は，シグナル伝達 系の違いなどにより, カチオン透過性のイオノトロ ピック型（iGluR）と，代謝調節型のメタボトロピ ック型（mGluR）に大別される (Fig. 1). ${ }^{1-3)}$ iGluR は，さらに外因性アゴニストに対する感受性の 相違などにより， $N$-methyl-D-aspartic acid (NMDA) 非感受性レセプターと，NMDA 感受性レセプター に分類される. ${ }^{4,5)}$ 前者には, GluR1-4 サブユニット から構成される DL- $\alpha$-amino-3-hydroxy-5-methylisoxasole-4-propianic acid（AMPA）型と，GluR5-7 及 び kainic acid（KA）1,2 サブユニットから組成され る KA 型が存在する。また，後者には NMDA レセ プター1（NR1）サブユニットと NR2A-D サブユ ニットが存在する。NR1 は NMDA レセプターの 機能的発現に不可欠なサブユニットであり， NR2A-D サブユニットは NR1 とへテロメリックな 複合体を形成して様々なチャネル機能調節を行うこ とが知られている. ${ }^{6}$ 一方， mGluRには，現在のと ころ mGluR1 から 8 までの 8 種のサブユニットが 存在するが, さらにアゴニスト感受性の違い，薬理 学的特性，あるいは共役する細胞内セカンドメッセ ンジャー系の違いなどにより 3 種類のサブタイプに 分類される. ${ }^{7,8)}$

一方，GluT は Glu のみならず，同じく興奮性ア ミノ酸であるアスパラギン酸を基質とするため, Excitatory amino acid transporter (EAAT) と称さ れ，現在までに EAAT1 (GLAST), EAAT2 (GLT-1), EAAT3（EAAC1），EAAT4 及び EAAT5 の 5 種類
が報告されている. ${ }^{9,10)}$ また，EAAT 以外に Glu を 細胞内に取り込む機構としては，ほかにXc-系が知 られており，この輸送系は細胞表面抗原である 4F2hc と cystine/Glu antiporter (xCT) がへテロ 2 量体を形成し，Cystine とGlu を基質とした交換輸 送である. ${ }^{11)}$

いくつかの独立した研究機関から，中枢神経系で 興奮性伝達物質として機能する Glu が，骨組織に おいて細胞間シグナル伝達に使用される内因性のパ ラクラインあるいはオートクライン因子の 1 つであ る可能性が提唱されている. ${ }^{12,13)}$ さらに Glu 作動性 神経により骨組織が神経支配を受けているという報 告もなされている. ${ }^{14,15)}$ すなわち，骨芽細胞の増 殖，分化あるいは成熟化に脳内神経伝達物質である Glu が，決定的な役割を演じる可能性が考えられ る。したがって本研究では，骨組織における Glu シグナル伝達機構を解明し，GluR あるいは GluT の機能修飾を通じて，骨粗鬆症や骨大理石症のよう な骨芽細胞による骨形成と破骨細胞による骨吸収と の骨代謝の不均衡によって引き起こされる様々な骨 代謝性疾患に対する新規治療的戦略を展開すること を目的とし，骨組織における GluR あるいは GluT の局在とその機能的な役割について追究した.

2. 骨芽細胞におけるグルタミン酸シグナリング 骨芽細胞における NMDA レセプターの発現を検 討したところ、NR1 と NR2D の mRNA とタンパ ク質がともに検出された。そこで，骨芽細胞に発現 する NMDA レセプターの機能的役割を解明するた め，NMDA レセプターのアンタゴニストである MK-801 存在下で骨芽細胞を培養し，分化の指標で ある Alkalinephosphatase（ALP）活性を測定した。 その結果，MK-801 刺激により ALP 活性は有意に 抑制された。さらに、NMDA レセプターの骨芽細 胞成熟化に対する役割を検討するため，カルシウム 蓄積量とオステオカルシンの発現を測定した。その 結果，MK-801 の添加によりカルシウム蓄積は有意 に抑制された。さらに，MK-801 を添加した細胞で は, 非添加細胞に比べてオステオカルシン発現は大 きく抑制された。

さらに, MK-801 以外の NMDA レセプター阻害 剂についてもその効果を検討した。 NMDA 結合ド メインのアンタゴニストである D- (-) -2-amino-5phosphonopentanoic acid 及びグリシン結合ドメイ 
ンのアンタゴニストである 6,7-dichloroquinoxaline2,3-dione の存在下骨芽細胞を培養し，カルシウム 蓄積量を測定した。その結果，今回使用したこれら すべての NMDA レセプターアンタゴニストは濃度 依存的にカルシウム蓄積を有意に抑制した。

Runx2 は骨形成における骨芽細胞分化のマス ターレギュレーター転写制御因子である。Runx2 の欠損により骨形成が抑制され，その heterozygous mutation においても鎖骨頭蓋形成不全症を引き起 こす。そこで次に，MK-801 存在下で骨芽細胞を培 養し，Runx2の DNA 結合能を測定した。その結果， MK-801 添加では DNA 結合能の有意な阻害がみら れた。 さらに, MK-801 添加により, Runx2のタン パク質と mRNAの発現減少が観察された。 以上の 結果により，骨芽細胞における NMDA レセプター が同細胞分化のマスターレギュレーターである転写 制御因子 Runx2 の発現と関連した機構により，細 胞分化を選択的に調節している事実が明らかとなつ た. ${ }^{16)}$

さらに骨芽細胞には NMDA レセプターに加えて, AMPA レセプターが発現していることを見い出し た。そして，同レセプターをアゴニストである AMPA を用いて刺激することにより，内在性 Glu の細胞外への遊離が引き起こされた。さらに，この AMPA 刺激による Glu 放出は，同レセプターアン タゴニストにより拮抗された。また骨芽細胞には GluT の EAAT1，EAAT2 及び EAAT3 が発現して いることを見い出した. ${ }^{17,18)}$ さらに $[3 \mathrm{H}] \mathrm{Glu}$ を用い た取り込み実験の結果，骨芽細胞には温度及び時間 依存的なグルタミン酸取り込み活性が認められた。 そして，その Glu 取り込み活性は, L- (-)-threo-3hydroxyaspartic acid (L-THA) や trans-4-carboxy-Lproline/L-trans-pyrrolidine-2,4-dicarboxylic acid (Ltrans-2,4-PDC) 等の特定の GlnT 阻害剂により, 有意に抑制された. ${ }^{19)}$

以上の結果により，特定のアミノ酸が細胞内情報 伝達物質として機能し得るために必要な 3 つの機 構，つまり (1)ベジクル内への興奮性アミノ酸を蓄積 し, 細胞外へ放出する機構 (VGLUT), (2)放出さ れたシグナルを受容するための入力系 (GluR) そ して(3)シグナルを終止するための終止系 (GluT) のすべてを骨芽細胞は備えていることが明らかとな った.
3. 破骨細胞におけるグルタミン酸シグナリング

骨吸収を担う破骨細胞における Glu シグナリン グ分子の発現解析及びその機能解析を行った．その 結果，いずれの GluR 発現も認められなかったが, Glu を取り込む働きを持つEAAT2，EAAT4 及び xCT の発現が認められた。そこで， [3H] Gluを用 いた取り込み実験を行った結果，破骨細胞には，温 度及び時間依存的なグルタミン酸取り込み活性が認 められ，さらに，GlnT 阻害剂を用いた結果，LTHA 及び L-trans-2,4-PDC ではこの Glu 取り込み は阻害されなかったが， $\mathrm{xCT}$ 阻害剤である $\mathrm{L}$ Homocysteic acid（HCA）により，その取り込みは 顕著に阻害された。さらに破骨細胞に Glu を暴露 し，分化の指標となる tartrate resistant acid phosphatase（TRAP）の活性を測定したところ，Gluの 濃度依存的に TRAP 活性が減弱し，その抑制作用 はHCAにより拮抗された。以上の結果により，破 骨細胞には，機能的な xCT が発現しており，破骨 細胞の分化を制御していることが明らかとなつ た. ${ }^{20)}$

さらに in vivo において骨組織における Glu シグ ナリング分子の生理学的意義及び病態生理学的意義 を検討することとした，そのために，骨粗鬆症モデ ル動物である卵巣摘出マウス（OVX マウス）を作 製し，そのマウスに Glu を投与し，骨密度測定及 び骨形態計測を行った。OVX マウスは sham 群と 比較して顕著な骨密度低下を示すが，卵巣摘出後か ら毎日 Glu を投与することにより，その投与量依 存的に骨密度の低下抑制作用が認められた。さらに 骨形態計測を行った結果，OVX マウスは sham マ ウスと比較して，骨芽細胞表面積及び破骨細胞表面 積が増加するが，OVX マウスに Glu を投与したマ ウスでは，骨芽細胞表面積には影響はみられなかつ たが，破骨細胞表面積の増加は顕著に抑制された。

以上の結果により，in vivoにおいても Glu は破 骨細胞の分化を抑制することにより，OVXにより 誘導される骨密度低下を顕著に抑制することが明ら かとなった. ${ }^{20)}$

\section{4. おわりに}

骨芽細胞及び破骨細胞に発現する Glu シグナリ ング分子の in vitro 機能解析から，Glu は骨芽細胞 においては NMDA レセプターなどの特定の GluR を介して分化促進作用を有し，逆に破骨細胞におい 


\section{Glutamate signaling in bone}

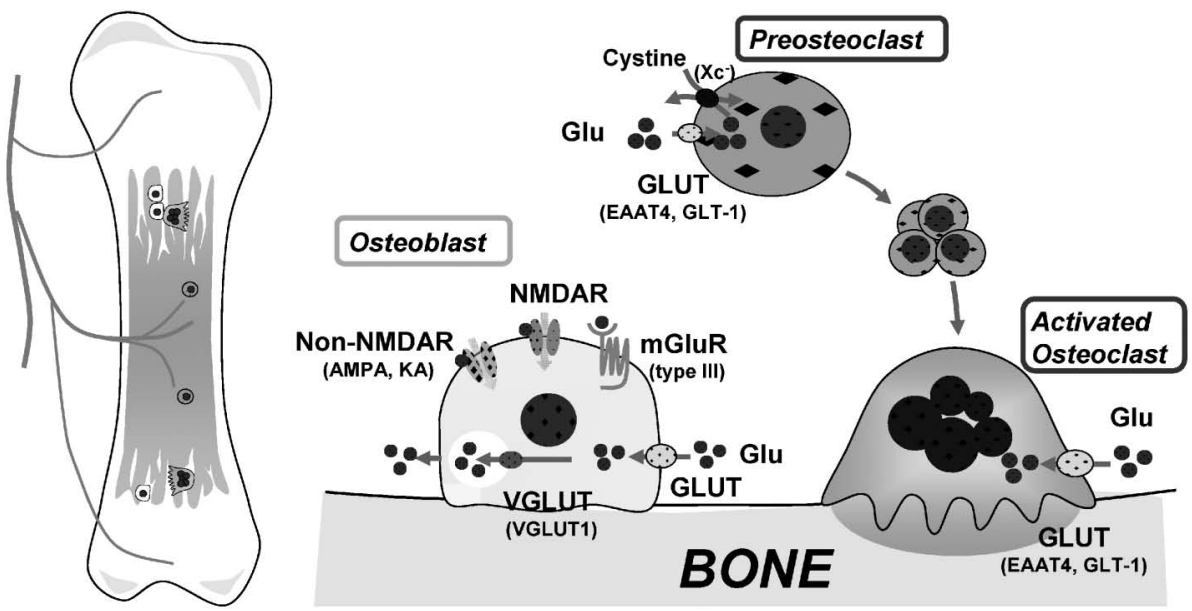

Fig. 2. Glu Signaling Machineries in Bone

ては xCT を介して分化抑制作用を示すことが明ら かとなった（Fig. 2)。さらにin vivoにおいても Glu が骨形成促進作用及び骨吸収抑制作用を発揮す る可能性が示唆された。 したがって in vivo 及び in vitro の両面においても Glu は特定のシグナリング 分子を介して骨リモデリングの維持機構に重要な役 割を果たしていることが明らかとなった. ${ }^{21-23)}$

われわれが示した本研究結果は，オートクライ ン・パラクラインメディエーターとしての Glu の 新規機能を明らかとしただけでなく，骨組織に発現 する Glu シグナリング分子を標的とした骨代謝性 疾患に対する新規治療的戦略の展開が可能となるこ とを示している.

\section{謝辞本研究を遂行する上において終始ご懇切} なるご指導とご鞭撻を賜りました，金沢大学医薬保 健研究域薬学系・米田幸雄教授, 摂南大学薬学部 · 荻田喜代一教授及び大阪府立大学農学部・中村洋一 教授に厚く御礼申し上げます。また，多大なるご協 力とご援助を頂きました金沢大学医薬保健研究域薬 学系・薬物学研究室の皆様に深く感謝いたします。

\section{REFERENCES}

1) Hollmann M., O'Shea-Greenfield A., Rogers S. W., Heinemann S., Nature, 342, 643-648 (1989).

2) Nakanishi N., Shneider N. A., Axel R., Neu- ron, 5, 569-581 (1990).

3) Yoneda Y., Kuramoto N., Kitayama T., Hinoi E., Prog. Neurobiol., 63, 697-719 (2001).

4) Wisden W., Seeburg P. H., Curr. Opin. Neurobiol., 3, 291-298 (1993).

5) Hollmann M., Heinemann S., Ann. Rev. Neurosci., 17, 31-108 (1994).

6) Lynch D. R., Guttmann R. P., Curr. Drug Targets, 2, 215-231 (2001).

7) Masu M., Tanabe Y., Tsuchida K., Shigemoto R., Nakanishi S., Nature, 349, 760-765 (1991).

8) Tanabe Y., Masu M., Ishii T., Shigemoto R., Nakanishi S., Neuron, 8, 169-179 (1992).

9) Kanai Y., Curr. Opin. Cell Biol., 9, 565-572 (1997).

10) Hinoi E., Takarada T., Tsuchihashi Y., Yoneda Y., Cuur. Drug Targets CNS Neurol. Disord., 4, 211-220 (2005).

11) Sato H., Tamba M., Ishii T., Bannai S., J. Biol. Chem., 274, 11455-11458 (1999).

12) Chenu C., Serre C. M., Raynal C., BurtPichat B., Delmas P. D., Bone, 22, 295-299 (1998).

13) Patton A. J., Genever P. G., Birch M. A., Suva L. J., Skerry T. M., Bone, 22, 645-649 (1998).

14) Serre C. M., Farlay D., Delmas, P. D., Chenu C., Bone, 25, 623-629 (1999).

15) Chenu C., Microsc. Res. Tech., 15, 70-76 
(2002) .

16) Hinoi E., Fujimori S., Yoneda Y., FASEB J., 17, 1532-1534 (2003).

17) Hinoi E., Fujimori S., Takarada T., Taniura H., Yoneda Y., Biochem. Biophys. Res. Commun., 297, 452-458 (2002).

18) Hinoi E., Fujimori S., Takemori A., Kurabayashi H., Nakamura Y., Yoneda Y., Brain Res., 943, 112-116 (2002).

19) Takarada T., Hinoi E., Fujimori S., Tsuchihashi Y., Ueshima T., Taniura H., Yoneda Y.,
Biochem. Pharmacol., 68, 177-184 (2004).

20) Hinoi E., Takarada T., Uno K., Inoue M., Murafuji Y., Yoneda Y., Am. J. Pathol., 170, 1277-1290 (2007).

21) Yoneda Y., Hinoi E., Nippon Yakurigaku Zasshi, 122, 14P-17P (2003).

22) Hinoi E., Takarada T., Ueshima T., Tsuchihashi Y., Yoneda Y., Eur. J. Biochem., 271, 113 (2004).

23) Hinoi E., Takarada T., Yoneda Y., $J$. Phamacol. Sci., 94, 215-220 (2004). 